\title{
NOTE
}

\section{TRUTH-IN-LENDING: JUDICIAL MODIFICATION OF THE RIGHT OF RESCISSION}

Congress adopted the Truth-in-Lending Act $^{1}$ in order "to assure a ineaningful disclosure of credit terms"' to the consumer obligor. ${ }^{8}$ One method adopted to accomplish this goal ${ }^{4}$ was to give to the con-

THE FOLIOWING CITATIONS WILL BE USED IN THIS NOTE:

R. Clontz, JR., Truth-IN-Lending Manual (3d ed. 1973) Thereinafter cited as TRUTH-IN-LENDING MaNUaL];

D. DOBBS, REMEDIES (1973) [hereinafter cited as D. DoBBS];

Burstein, There's Truth in Lending, But ls There Right in Rescission?, 2 REAL EsTATE REv. 83 (Summer 1972) [heremafter cited as Burstein].

1. Consumer Credit Protection Act, 15 U.S.C. $\S \S 1601-81$ (1970). The Act was impleinented by Federal Reserve Board Regulation Z, 12 C.F.R. § 226 (1974). See generally Garwood, Truth in Lending-A Regulator's View, 29 BUs. LAWYER 193 (1973); Kintner, Henneberger \& Neill, $A$ Primer on Truth in Lending, 13 ST. Lous U.L.J. 501 (1969); Tanner, Truth in Lending and Regulation Z-A Primer, 6 GA. ST. B.J. 19 (1969); Note, Truth in Lending: The Impossible Dream, 22 CASE W. RES. L. REv. 89 (1970); Comment, Private Remedies Under the Truth-in-Lending Act: The Relationship Between Rescission and Civil Liability, 57 IowA L. REv. 199 (1971).

2. 15 U.S.C. $\$ 1601$ (1970). The Act requires disclosure in clear and conspicuous language so that the consumer can make an informed choice between alternative credit terms. See id. § 1631; Bissette v. Colonial Mortgage Corp., 340 F. Supp. 1191, 1193 (D.D.C. 1972); Ratner v. Chemical Bank N.Y. Trust Co., 329 F. Supp. 270, 276 (S.D.N.Y. 1971); 114 CoNG. REc. 1615 (1968) (remarks of Representative Helstoki).

3. The consunier is "the party to whom credit is offered or extended . . ." 15 U.S.C. $\$ 1602(h)(1970)$. Section 1635, however, uses the word "obligor" to describe the person contracting the debt. Id. $\$ 1635$.

4. The Act provides several means of enforcement, some of which are designed to penalize the non-disclosing creditor and others of which afford relief to the consumer. A civil penalty, for example, is authorized by the following language:

(a) [A]ny creditor who fails to conply with any requirement imposed under this chapter .... with respect to any person is liable to such person in an amount equal to the sum of -

(1) any actual damage sustained by such person as a result of the failure;

(2) (A) in the case of an individual action twice the amount of any finance charge in connection with the transaction, except that the liability under this subparagraph shall not be less than $\$ 100$ nor greater than $\$ 1000.28$ Pub. L. No. 89-320, \$ 408 (Oct. 28, 1974), amending 15 U.S.C. $\$ 1640$ (1970).

Earlier decisions characterized this civil bability as being remedial in nature and required the consumer to elect between pursuing this renedy or rescinding the contract. In Bostwick v. Colen, 319 F. Supp. 875 (N.D. Ohio 1970), for example, the court stated that "the civil liability section is remedial rather than punitive in nature . ..." 
sumer the right to rescimd a credit agreement ${ }^{5}$ if the creditor fails to disclose information required by the Act. This right applies to those transactions where a security interest is created in "the residence of the person to whom the credit is extended ...." Unlike common

$I d$. at 878. This, in turn, led the court to require election of remedies since "a remedy of rescission is inconsistent with a remedy based on a theory of affirmance of the transaction and . . . an election of the former constitutes an abandonment of the latter . . .." Id. at 877. See also Ratuer v. Chemical Bank N.Y. Trust Co., 329 F. Supp. 270, 282 (S.D.N.Y. 1971). Other courts, however, have concluded that section 1640 operates as a penalty on the creditor and have avoided the doctrine of election of remedies. See, e.g., Mourning v. Family Publications Serv., Inc., 411 U.S. 356, 376 (1973); Eby v. Reb Realty, Inc., 495 F.2d 646, 651 (9th Cir. 1974) ("[I]f the civil liability provision is ... viewed as penal and not remedial, it is not mconsistent with a right of rescission since civil liability is not then aimed at making the borrower whole."). For a discussion of the doctrine of election of remedies, see D. Dobss $\$ 1.5$. See generally Comment, supra note 1; 1971 U. Toledo L. Rev. 573. The original Act did not include any provision for actual damages. It is possible, therefore, that the issue of election of remedies will endure considerable litigation before being finally settled, since the damages section of the recent amendment once inore raises the question of whether the civil relief is remedial or penal.

In addition to the civil penalty, the Act also provides that "in the case of any successful action to enforce the foregoing hability, the costs of the action together with a reasonable attorney's fee as determined by the court" may be awarded. 15 U.S.C. \$ 1640 (a) (2) (1970). It is apparently within the court's discretion to determine the number of billable hours reasonably attributable to the case as well as the lourly rate which is billed. See, e.g., Philbeck v. Timmers Chevrolet, Inc., 361 F. Supp. 1255, 1262 (N.D. Ga. 1973); Ljepya v. M.L.S.C. Properties, 353 F. Supp. 866, 868 (N.D. Cal. 1973).

The criminal penalty provides for a fine of not more than $\$ 5,000$ and/or imprisonment not to exceed one year. 15 U.S.C. $\$ 1611$ (1970). It applies to whoever willfully and knowingly

(1) gives false or maccurate information or fails to provide information which he is required to disclose under the provisions of this subchapter or any regulation issued thereunder,

(2) uses any chart or table authorized by the Board under section 1606 of this title in such a manner as to consistently understate the annual percentage rate detennined under section $1606(\mathrm{a})(1)(\mathrm{A})$ of this title, or

(3) otherwise fails to comply with any requirement imposed under this subchapter. Id.

The Act requires the United States Attomey General to submit an annual report to Congress regarding his enforcement of the Act and any recommendations that he may have. Id. $\$ 1613$. Attorney General Kleindienst reported that in 1972 only four persons were indicted for violations of the Act. 1 TRUTH-IN-LENDING MANUAL iा 3.08[2], at 3-140 (1973). One commentator lias suggested that there will be few prosecutions under the Act because it is "practically impossible to 'prove beyond a reasonable doubt' that the average small creditor was either 'willful or knowing' as to the complex requirements on which he is impaled under the Act and Regulation Z." Id. II 3.08[1], at 3-138.

5. The Act extends the right of rescission "until midnight of the third business day following the consummation of the transaction or the delivery of the disclosures required ...." 15 U.S.C. $\$ 1635$ (a) (1970). This provision also makes the creditor's security interest void after the consumer has exercised his right to rescind. Id. $\$ 1635$ (b).

6. Id. $\$ 1635(\mathrm{a})$. 
law rescission, ${ }^{7}$ the Act provides that the consumer can exercise his right to rescind the contract without first tendering the consideration that he has received. ${ }^{8}$ While this literal interpretation of the Act has been applied in one line of cases, ${ }^{9}$ some recent decisions have judicially modified the Act to the extent that a count is afforded the discretion to require a consumer to tender the consideration before rescission of the contract will be effective. ${ }^{10}$ Such conditional rescission will apparently be ordered only when the consumer seeks both rescission and a civil penalty" and when these two remedies in combination will "result in an unduly harsh penalty" to the creditor. ${ }^{12}$ This Note will examine these different interpretations and suggest that the former is preferable since it more effectively implements the intent of Congress. ${ }^{13}$

\section{DEPARTURE FROM TRADITIONAL RULES}

To understand how the Act changes the traditional sequence of tender and rescission it is useful to review the nonstatutory rules that ordinarily apply to a consumer-creditor relationship.

Traditional Rules. Generally, rescission results in the annullment or abrogation of a contract ${ }^{14}$ and should be accompanied by restitution of the consideration exchanged in order to restore the parties to the status quo ante. ${ }^{15}$ Restitution is an essential element of rescission, ${ }^{16}$

7. See notes 18-19 infra and accompanying text.

8. "Upon the performance of the creditor's obligations [which are to be performed after notice of rescission] under this section, the obligor shall tender the property to the creditor . . . ." 15 U.S.C. \& 1635(b) (1970). See generally Comment, Truth in Lending: Problems with the Right of Rescission, 7 WIILAMETTE L.J. 119 (1971).

9. See, e.g., Sosa v. Fite, 498 F.2d 114, 117-18 (5th Cir. 1974); Hank's Auto Sales, Inc. v. Fisher, 38 Ohio App. 2d 1, 5, 310 N.E.2d 259, 262 (1973).

10. See, e.g., Palmcr v. Wilson, 502 F.2d 860, 862-63 (9th Cir. 1974); Ljepya v. M.L.S.C. Properties, 353 F. Supp. 866, 868 (N.D. Cal. 1973).

11. For a discussion of the civil penalty, see note 4 supra.

12. Palmer v. Wilson, 502 F.2d 860, 862 (9th Cir. 1974). The Palmer court further stated:

The propriety of such a conditional decree of rescission ... will depend on

the equities present in a particular case, as well as consideration of the legis-

lative policy of full disclosure that underlies the Truth in Lending Act and the remedial-penal nature of the private enforcement provisions of the Act. Id.

For a discussion of guidelines to be used by a court in deciding whether or not to order conditional rescission, see note 69 infra.

13. See notes 73-75 infra and accompanying text.

14. "Rescission as a general rule must be exercised in toto and is applied to the contract in its entirety with the result that what has been done is wholly undone and no contract provisions remain in force to bind either of the parties." Merickel v. Erickson Stores Corp., 255 Minn. 12, 16, 95 N.W.2d 303, 306 (1959). See also 17 AM. JUR. 2d Contracts $\$ 516$, at 1002 (1964).

15. Restitution attempts to restore the parties to their original positions. See, e.g., 
for in its absence one of the parties may be unjustly enriched on a void contract. $^{17}$ Therefore, rescission at law may be effected only if the rescinding party makes an unconditional offer (tender) to return the consideration that he received. ${ }^{18}$ Once the rescinding party has given notice of rescission and has tendered, the contract is void and the rescinding party may bring an action in replevin or assumpsit to have the consideration that he has provided restored to him. ${ }^{19}$ The contract is

Medivox Prods. Inc. v. Hoffman-LaRoche, Inc., 107 N.J. Super. 47, 256 A.2d 803 (1969) (rescission "is generally only available when the party seeking to rescind can restore the other party to the status quo," id. at 75-76, 256 A.2d at 818, citing 17 AM. Jur. 2d Contracts $\$$ 512, at 994 (1964)); E.T.C. Corp. v. Title Guar. \& Trust Co., 271 N.Y. 124, 127, 2 N.E.2d 284, 286 (1936); Evans v. Brubaker, 207 Okla. 42, 44, 247 P.2d 511, 513 (1952); Brandtjen \& Kluge, Inc. v. Shonka, 2 Utah 2d 223, 226, 272 P.2d 155,156 (1954). See also S. Winliston, A Treatise on the Law of Contracts $\$$ 1454 , at 3-4 (3d ed. W. Jaeger 1970). There are some minor exceptions to this general rule that restitution is a prerequisite to rescission of a contract. See 17 AM. JUR. 2d Contracts $\& 513$, at 797 (1964).

16. "Restitution is an integral part of rescission and defendants cannot have the benefits of rescission without assuming its responsibilities." Johnston v. Gilbert, 234 Ore. 350, 354, 382 P.2d 87, 89-90 (1963) (footnotes omitted). However, one commentator has cautioned that "[t]o the extent that the law of restitution is a law of readjustments, the principle against unjust enrichment furnishes a goal, but other principles must be sought out and established to reach solutions to many of the problems." D. DoBBs $\S 4.1$, at 227.

17. The rescinding party is given the right to void a contract at law if, for example, he is "defrauded or if he enters a contract under a basic mistake, or if his contract is unenforceable at his option because of infancy or lack of a writing . . ." D. DoBBs $\S 4.8$, at 293 (footnotes omitted). See also S. Wirliston, supra note 15 , $\S 1454$ et seq.

18. See 17 AM. JuR. 2d Contracts $\$ 512$, at 996 (1964). "[T]t has been held that it is necessary, as a condition to bringing an action at law based on the rescission of a contract, previously to return or tender bonds, mortgages, or mortgage certificates received by the plaintiff as consideration." Id. $\$ 515$, at 1000 . This rule is not universally favored and one commentator has suggested that "much improvement would result if the rigid rule of restoration were abandoned altogether ..." D. DoBBs $\S 4.8$, at 297.

19. "The theory here is that the court has nothing to do with the rescission of the transaction; that is accomplished by the plaintiff when he notifies the defendant and returns what he received under the transaction." D. DoBBs $\S 4.8$, at 293 .

However, if the plaintiff is sumg for rescission in equity, he does not have to make restitution before commencing suit "[s]ince rescission is not accomplished 'in equity' until the court so decrees." Id. at 294. See also Lightner v. Karnatz, 258 Mich. 74, 241 N.W. 841 (1932). This has been explained by one commentator in the following manner:

Many of the courts have, in dealing with this question, completely lost sight of the plain distinction between the equitable remedy of rescission or cancellation ... and the legal remedies, based upon rescission of a contract by the act of a party thereto, where, in the act of rescission itself, the plaintiff must restore or attempt to restore the consideration, since, in legal theory, the ex parte act of rescission reinvests him with the legal title to the thing for the possession of which he subsequently sues, and must, therefore, be conditioned upon a surrender of the thing already received by him in pursuance of the transaction which he thus avoids. 5 J. POMERox, POMEROY's EQUTTY JURISPRUDENCE AND EQUTTABLE REMEDIES \& 2110, at 4765 (2d ed. 1919). 
rescinded at law without a court decree; judicial action is necessary only to assist the rescinding party in recovering his property. In order to rescind a contract by his own act, however, a party inust have a substantive basis for doing so-that is, the contract must be voidable.

Assume, for example, that a consumer purchased storm windows costing $\$ 2,000$ and that he paid for them by check. Shortly thereafter, he discovered that the contract was voidable, ${ }^{20}$ rescinded the agreement by returning the windows to the seller, and demanded restoration of his payment. If the seller accepted the storm windows but refused to return the money paid, the consumer could bring an action at law to recover his property, but he would be at a serious disadvantage. $\mathrm{He}$ not only would have lost the use of the storm windows and his money, but he would also bear the risk that by the time he obtains an enforceable judgment the seller may no longer be solvent. Furthermore, the burden of bringing suit would fall entirely on the consumer, who must assume hitigation expenses if he is to recover any of the consideration that he has paid.

Statutory Departure from Traditional Rules. The Truth-inLending Act provides the consumer with a new substantive basis for voiding a credit agreement ${ }^{21}$ and reorders the sequence of rescission and tender. ${ }^{22}$ If the buyer of the storm windows purchased the goods on credit ${ }^{23}$ and extended to the creditor a second mortgage on his res-

20. See note 17 supra.

21. See note 31 infra. The provisions of section 1635 are also incorporated in section 5.204 of the Uniform Consumer Credit Code.

22. See 15 U.S.C. $\$ 1635$ (b) (1970); Regulation Z, 12 C.F.R. $\$ 226.9$ (d) (1974). See also Burstein 90.

23. The provisions of section 1635 (rescission) are triggered only if it is first determined that a credit transaction has occurred. The Act provides:

(e) The term "credit" means the right granted by a creditor to a debtor to defer payment of debt or to incur debt and defer its payment.

(f) The term "creditor" refers only to creditors who regularly extend, or arrange for the extension of, credit for which the payment of a finance charge is required . . . 15 U.S.C. $\$ 1602$ (e), (f) (1970); see 12 C.F.R. \$ 226.2(1) (m) (1974).

Similarly, Regulation $Z$ provides:

(k) "Consumer credit" means credit offered or extended to a natural person, in which the money, property, or service which is the subject of the transaction is primarily for personal, household, or agricultural purposes and for which either a finance charge is or may be imposed or which pursuant to an agreement, is or may be payable in more than four installments. Id. $\$ 226.1$ (k) (emphasis added);

see Young v. Tri-City Remodeling Enterprises, Inc., 335 N.Y.S.2d 308 (City Ct. Albany 1972 ).

The authority of the Federal Reserve Board to establish the "more than four installments" rule was challenged in Mourning v. Family Publications Serv., Inc., 411 U.S. 356 (1973). In that case, the district court entered sunmary judgment for the purchaser of a magazine subscription under a thirty-month installment contract since the disclosure 
idence as security, ${ }^{24}$ the transaction would be subject to the disclosure requirements of the Act. If the creditor failed to accurately report the annual percentage rate of interest, ${ }^{25}$ for example, the consumer could rescind the contract by simply giving the creditor notice of his intent to rescind. ${ }^{20}$

requirements of the Truth-in-Lending Act were not met. This decision was sustained by the Supreme Court in an opmion that characterized the "rule" as reasonably related to the objective of preventing creditors from concealing finance charges in the cash price.

In a series of Public Position Letters, the Board has clarified the terms used in Regulation $Z$. "[T]he term 'credit,' for the purposes of Truth-in-Lending, assumes a contractual relationship voluntarily entered, between creditor and debtor." Excerpts from FRB Letter of July 14, 1969, [1969-1974 Transfer Binder] CCH Consumer CREDIT Guide T 30,107 , at 66,045 . Therefore, taxes and assessments levied by a municipality are not within the meaning of the term. Excerpts from FRB Letter of Oct. 15, 1969, No. 153 , id. $\int 30,494$, at 66,221 . Additionally, if one is not contractually bound to make installment payments, the "credit" requirement is not met. Excerpts from FRB Letter of June 3,1969, id. \ 30,041, at 66,021-22. In order for credit, as used in the Truth-in-Lending Act, to be extended, there must be a finance charge involved. Excerpts from FRB Letter of May 28, 1970, No. 337, id. If 30,392, at 66,181-82 (an option contract constitutes a credit transaction); Excerpts from FRB Letter of Mar. 13,1970 , No. 286 , id. I 30,526 , at 66,233 (a service charge or additional fee beyond the purchase price of an item must be charged to the consumer in order for a lay away plan to be subject to the Act); Excerpts from FRB Letter of July 8, 1969, No. 32, id. If 30,434, at 66,200-01 (professional groups who allow their patients or customers to pay bills in more than four installinents are subject to the Act if they require a finance charge).

It should be pointed out, however, that the Act does not apply to casual loans if the lender does not regularly make such loans, nor to enterprises that extend credit only through the use of independent credit agencies such as Master Charge, American Express, or Diners' Club. See Kintner, Henneberger \& Neill, supra note 1, at 502.

24. A security interest must be created in the consumer's residence in order for the section to be applicable. 15 U.S.C. $\$ 1635$ (a) (1970). Excepted from the coverage of this section, however, are first liens "against a dwelling to fimance the acquisition of that dwelling." Id. $\$ 1635(\mathrm{e})$; see Regulation Z, 12 C.F.R. $\S 226.9(\mathrm{~g})$ (1974). This exception extends to

(1) first liens, whether created, retained or assumed, used to finance acquisi-

tion of the residence in which the consumer resides or intends to reside;

(2) first liens that are retained or acquired to finance construction of a new house;

(3) any subordinated lien that was exempt at the time it was created;

(4) certain advances made for agricultural purposes. Id.

See also 1 CCH CONSUMER CReDit GUIDE T 1810, at 3193 (1974). But "[a]ll second mortgages on the debtor's principal residence, along with many other liens such as mechanics and materialnen's liens fall within the scope of the Act." Comment, supra note 8 , at 122 .

25. See 15 U.S.C. $\$ 1606$ (1970).

26. Id. $\S 1635$ (a). For this notice to be effective it must be in writimg. $1 \mathrm{CCH}$ Consumer CREDIT GUIDE If 1860, at 3202 (1974). If written notification is sent by mail, it is deemed given when the instrument is placed in the mail box. If given by telegraph, the notification is effective when the telegram is filed for transmission. Other documentary notification is "given" when it arrives at the creditor's place of busi- 
When a consumer exercises his right to rescind under the Act, any security interest extended to the creditor becomes void. ${ }^{27}$ Upon notice of rescission, the creditor has ten days in which to return the property he has received from the consumer ${ }^{28}$ and to "take any action necessary or appropriate to reflect the termination of any security interest created under the transaction." ${ }^{29}$ After the creditor performs these statutory obligations, the consumer must tender the property he has received pursuant to the contract. ${ }^{30}$

Under the Act, a consumer has nore protection against deceptive creditors than is provided by nonstatutory law. He is extended a new substantive basis for rescinding a contract: the creditor's nondisclosure of credit terms as required by the Act. ${ }^{31}$ Furthermore, the consumer can

ness. 1 TRUTH-IN-LENDing MANUAL $\{5.03$ [1], at 5-30 to 31 . The form of the notice that the creditor must give to the consumer of his right to rescind is set out more extensively in 12 C.F.R. $\$ 226.9$ (b) (1974).

27. 15 U.S.C. $\$ 1635$ (b) (1970). Although this section of the Act requires the creation of a security interest in a residence, id. $\$ 1635(\mathrm{a})$, it would appear that once this threshold requirement is met all security interests created in that transaction would become void upon rescission. Thus, if a consumer, in one transaction, gave the creditor a security interest in his residence and his car, both security interests would become void.

28. Id. $\S 1635$ (b); see Regulation Z, 12 C.F.R. $\S 226.9$ (d) (1974). It is also of particular significance that "[w]hen a customer exercises his right to rescind . . . he is not liable for any finance or other charge ...." Id. It has been determined, for example, that commitment fees received froin the consumer are "finance charges" within the meaning of section 1635. Excerpts from FRB Letter of April 17, 1970, [1969-1974 Transfer Binder] $\mathrm{CCH}$ Consumer CREDIT GUIDE $\pi$ 30,355, at 66,161. See also Excerpts froin.FRB Letter of May 28, 1970, No. 337, id. \ 30,392, at 66,181.

29. 15 U.S.C. $\S 1635$ (b) (1970).

30. The tender may be made "at the location of the property or at the residence of the obligor, at the option of the obligor." Id. This would seem to place the burden of retrieving the property on the creditor, since the creditor's failure to take possession of the tendered property within ten days causes title to be vested in the consunner without any obligation to pay for it. Id.; see Regulation Z, 12 C.F.R. $\$ 226.9$ (d) (1974). This, of course, raises the question of what happens if it is impossible for the creditor to take possession-for example, if there were a blizzard. 1 Truth-IN-Lending Manual If 5.03[5], at 5-35. No provision was made for "legal excuse," so apparently the title would still vest in the consumer.

It is unclear what the result would be if the contract expressiy required that the consumer liad to return the property to the place of the creditor's business in order to rescind the contract. The court would probably give effect to a tender of the property at the residence of the creditor or at its location but assess damages against the consumer for the cost of moving the property to the creditor's place of business.

31. 15 U.S.C. \$ 1635(a) (1970); see Regulation Z, 12 C.F.R. $\$ 226.9$ (1974).

A literal reading of the Act suggests that the consumer is provided two new substantive grounds for rescinding a credit agreement. First, he is guaranteed the absolute right to rescind within three business days following the consummation of the contrach, regardless of whether the creditor lias complied with the disclosure requirements. Second, if the creditor has not made the proper disclosures, the consumer may rescind until three days after disclosure is made. In other words, there are actually two three-day 
effect rescission merely by notifying the creditor of his intent to do so. ${ }^{32}$ If the creditor has not returned the consuner's property within ten days after receiving notice of rescission, the consumer can sue for restoration of his property. However, once the creditor has returned the consumer's property and cancelled the security interest, the consumer must tender the creditor's consideration. ${ }^{33}$ Thus, the effect of the Aot is to shift the burden of performing first from the consumer to the creditor. In addition, if the creditor does not take possession of the consideration tendered by the consumer within ten days from the time it is tendered, ownership of the property will vest in the consumer without any further obligation on his part to pay for it. ${ }^{34}$ In general, the provisions of the Act seem to represent a conscious attempt to place the consumer in a much stronger bargaining position than he enjoys under the traditional rules of rescission.

\section{JUDICIAL CONDITIONS FOR RESCISSION}

Some courts have been troubled by the favorable position in which the Aot places the consumer and have tempered the apparent unfairness to the creditor by inposing nonstatutory conditions upon the consumer's right to rescimd. ${ }^{35}$ The first reported case in which a court

periods during which the consumer may rescind, instead of one. The first is truly a "cooling-off" period. But the second, which arises only if the creditor discloses the required information after the initial three day period has run, is not a "cooling-off" period at all. Instead, it serves as a remedial device to make the deceived consumer whole again. There is no shopping around or comparison of alternative credit arrangements during this period. However, it does work almost as a penalty on the creditor, while relieving the consumer of an unwanted credit obligation. At a minimun, it encourages creditors to disclose fully in compliance with the statute prior to consummation. By his own efforts (in the form of disclosure in accordance with the terms of the Act), the creditor may avoid rescission of the credit agreement and possible forfeiture of property transferred thereunder. See generally Comment, Timing of Truth-in-Lending Disclosures: A Dilemma for Mortgage Lenders, 58 Iowa L. REv. 389 (1972), in which it is suggested that disclosure should be made well before the consunnnation of a credit transaction in order to "meaningfully utilize this credit information in bargaining negotiations." Id. at 395.

32. But see Palmer v. Wilson, 502 F.2d 860 (9th Cir. 1974).

33. Thus, the consumer retains the property until tender is required. However, the consumer may have to give the creditor a credit for the use of the creditor's property. See Eby v. Reb Realty, Inc., 495 F.2d 646, 648 (9th Cir. 1974) (amount returned to consumer reduced by the rental value of the premises during the consumer's possession).

34. 15 U.S.C. $\$ 1635$ (b) (1970). The Act is unclear as to whether there are any limits on when the consumer can tender in order to start this forfeiture period running. Case law has further confused this issue. See notes 110-14 infra and accompanying text.

35. See, e.g., Palmer v. Wilson, 502 F.2d 860 (9th Cir. 1974); Eby v. Reb Realty, Inc., 495 F.2d 646 (9th Cir. 1974); Ljepya v. M.L.S.C. Properties, 353 F. Supp. 866 (N.D. Cal. 1973). 
departed from a literal interpretation of the Act was Ljepya v. M.L.S.C. Properties. $^{36}$ In this case, borrowers brought suit seeking enforcement of the Act on the basis that a mortgage broker had not properly disclosed that forty-eight percent of the principal amount ${ }^{37}$ of a second mortgage he had obtained for them was for commissions. ${ }^{38}$ The court

36. 353 F. Supp. 866 (N.D. Cal. 1973).

37. The Act does not attempt to regulate finance charges or to interfere with trade practices except to the extent that such practices may be inconsistent with its provisions. See generally Regulation Z, 12 C.F.R. $\$ \$ 226.6(\mathrm{~b})$, (c) (1974); Excerpts from FRB Letter of April 20, 1972, No. 596, [1969-1974 Transfer Binder] CCH CoNsumer CREDIT Guide II 30,840, at 66,367; H.R. REP. No. 1040, 90th Cong., 2d Sess. (1968); 1 TrUTH-IN-LENDING MaNUAL $\prod 2.03$, at 2-6; Tanner, supra note 1 .

Consequently, the only significance of the forty-eight percent figure used here is to show the materiality of the broker's nondisclosure. A second mortgage could have been procured for a ten percent, rather than a forty-eight percent, commission to the brokers "because of the demand for the property for development purposes" at that time. $353 \mathrm{~F}$. Supp. at 867 . This is precisely the type of practice that the disclosure requirements were intended to correct. A recurring theme in the congressional debates was that the consumer has been historically subjected to the unscrupulous tactics of creditors who would engage in practices which, if not fraudulent, were calculated to confuse consumers. See 114 Cong. Rec. 1611 (1968) (remarks of Representative Cahill). As was explained by one Congressman:

What the consumer does need is to be told the truth in a form which is meaningful to him. Significant truth in the area of credit terms for all transactions presented in a uniform fashion, so that the consumer can compare credit terins with the same ease that he is able to compare initial price. Id. at 1595 (remarks of Representative Halpern).

See generally Garwood, $A$ Look at Truth In Lending-Five Years After, 14 SANTA ClARA LAWYER 491, 492-93 (1974). This purpose was explicitly stated in the Act itself: "It is the purpose of this subchapter to assure a meaningful disclosure of credit terms so that the consumer will be able to compare more readily the various credit terms available to him and avoid the uninformed use of credit." 15 U.S.C. \$ 1601 (1970) (emphasis added). The Ljepya court characterized the nondisclosure by the mortgage broker as a "part of a deception to cover up an extortion and a conflict of interest" and concluded that the Act was applicable. $353 \mathrm{~F}$. Supp. at 868.

38. The facts of this case are somewhat complicated, but nevertheless essential to a thorough understanding of the holding. The plaintiffs were owners of land valued at $\$ 225,000$, on which there was a first mortgage for $\$ 93,000$. In 1971 , they obtained a second morgage of $\$ 18,000$ from Arms, a real estate broker, who placed the mortgage with one of his customers. When the plaintiffs were delinquent in paying interest on the second mortgage, Arms obtained an assignment thereof from his customer and recorded a notice of default. Fearing that Arms was "scheming to foreclose" on them, the plaintiffs went to Lopes to obtain a new second mortgage to pay off the existing second mortgage. Lopes, a real estate agent, was acting as a representative of numerous parties: (1) the plaintiffs; (2) his associate Paulson; (3) HLC and its parent company, M.L.S.C. Properties, Inc., which "were in the business of setting up trusts on mortgages and disposing of participations in those trusts to individual beneficiaries." $353 \mathrm{~F}$. Supp. at 867. Lopes required of the plaintiffs a commission of $\$ 6,120$ for HLC and $\$ 5,400$ for Paulson. It was this dual commission of $\$ 11,520$ that the court deemed improperly disclosed pursuant to 15 U.S.C. $\& 1639$ (a)(2) (1970), which requires disclosure of "[a]ll charges, individually itemized, which are included in the amount of credit extended but which are not part of the finance charge." This failure to disclose gave rise 
granted the maximum civil penalty and attorney fees but conditioned rescission on tender by the obligors: "Plaintiffs [consumers] are entitled to rescission, upon repaymg within ten days of judgment the principal of the second mortgage loan ... together with sucli sums as . . . the second mortgagee has recently paid to the first mortgagee ....."30 The court was untroubled by the fact that it had conditioned rescission on tender, despite the language of the Act whiclr seems to provide to the contrary. ${ }^{40}$

The next case which judicially modified the express terms of the Act was Eby v. Reb Realty, Inc. ${ }^{41}$ The Eby court held that a consumer cannot be compelled to elect between exercising his right to rescind the contract ${ }^{42}$ and suing the creditor for a civil penalty; ${ }^{43}$ rather he may seek both forms of relief at the same time. ${ }^{44}$ Although the court avoided forcing the consuner to elect between a civil penalty and rescission, it did qualify its opimion:

[W] do not say that a court must always grant both forms of relief when requested. These two separate provisions can result in a sometimes harsh penalty. In the absence of any clear congressional statement, we think a request for both forms of relief is addressed to a court's sense of equity and may be properly denied in appropriate cases. ${ }^{45}$

The court viewed the question of whether or not both types of relief should be granted as a matter of the trial court's "equitable discre-

to a cause of action under section 1635 (b) because the consumer has a right to rescind until there has been a "delivery of the disclosures required under this section and all other material disclosures required under this part." Id. $\S 1635$ (a).

39. 353 F. Supp. at 868 . There is no explanation whatever as to why the court allowed the consumer only ten days from the date of judgment to make a tender to the creditor. If the creditor's violations were as flagrant as the court suggested, see note 37 supra, it is strange that the court chose a ten day figure that is in no way imposed by the Act.

40. "[W] return to the obligor any money or property given .... Upon the performance of the creditor's obligations under this section, the obligor shall tender the property to the creditor . ..." 15 U.S.C. $\$ 1635(b)$ (1970). This language implies that the only time that the consumer must tender is after the creditor has fulfilled his obligations. This point in time has to be after rescission because the creditor's obligations do not arise until after rescission.

41. 495 F.2d 646 (9th Cir. 1974).

42. 15 U.S.C. \& 1635 (1970).

43. Id. $\$ 1640(\mathrm{a})$.

44. 495 F.2d at $651-52$. Some courts consider the civil penalty to be a remedy and apply the doctrine of election of remedies. See note 4 supra.

45. Id. at 652 . In this case, a real estate brokerage firm was attempting to foreclose a second mortgage that it had taken on the plaintiff's home as part of the broker's sale to the plaintiff. The brokerage firm failed to disclose the credit terms or the right of rescission granted by the Act. Id. at 647 . 
tion." ${ }^{36}$ In this instance it concluded that the lower court had not abused its discretion by awarding both rescission and the civil penalty. ${ }^{47}$

The Eby court did not consider the question of conditional rescission; however, it was the first court to judicially modify the Act by subjecting the enforcement provisions to the "equitable discretion" of the judiciary. ${ }^{48}$ This modification was perhaps based on the well-recogmized principle that, in interpreting a statute, a court may depart from a literal reading if its sense of equity and fair play so dictate. ${ }^{40}$ The sense of equity is "synonymous with [interpreting the] 'spirit" or "principle" " of the statute. ${ }^{50}$ By departing from the precise terms of a statute, courts attempt to give effect to the intent of the legislature rather than to the language chosen to express that intent. ${ }^{\text {61 }}$ Generally, such modification is appropriate where: (1) the language of the statute is so narrow that it precludes application of the law to a situation which the court believes the legislature intended it to reach; or (2) the statutory language is so ambiguous that its literal interpretation would seein to expand the coverage of the statute beyond that which the legislature intended. ${ }^{52}$

The first test clearly does not justify the Eby court's modification of the Act since the basic thrust of its decision serves to expand, rather than narrow, the application of the enforcement provisions. By characterizing the civil liability provisions of the $\mathrm{Act}^{53}$ as penal, the court negated the rationale underlying election of remedies. The Eby court stated, "[I]f the civil provision is so viewed as penal and not remedial, it is not inconsistent with a right of rescission since civil liability is not

46. Id. at 652 .

47. Id.

48. This dictum was relied upon in Palmer v. Wilson, 502 F.2d 860 (9th Cir. 1974), wherein the court conditioned rescission on tender by the obligor.

49. 2A C. Sands, SutHertand Statutory Construction $\$ 54.01$, at 351 (4th ed. 1973). The court's sense of equity slould not be confused with the procedures used by a court of equity in dealing with rescission and restitution. See note 19 supra.

50. Id.

51. Id. \& 54.03, at 356-58 $\mathrm{nn} .6-13$.

52. Id. $\$ 54.04$, at 358 . The second of these principles is designed to limit the remedy provided by the statute so that it will not work to effect a mischief not intended by Congress.

[I]t also lrappens sometimes that people speak in imprecise generalities which in conventional usage could reasonably be found to embrace more than there is any purpose or reason to include. It is therefore a correlative of equitable interpretation, in recognition of this insight about imprecision sometimes encountered in the use of language, that when there is doubt about how inclusively a statute should be construed to apply, if the miscliief that it was enacted to remedy can be perceived it will be construed to apply only so far as is needed in order to effectuate the remedy. II.

53. 15 U.S.C. \& 1640 (1970). See note 4 supra. 
then aimed at making the borrower whole." soned that both forms of relief were necessary to avoid undermining the effectiveness of the Act. ${ }^{55}$

The second test for statutory modification was at least arguably met since the Eby court found some ambiguity in the Act in that Congress was silent as to whether the doctrine of election of remedies should apply to the enforcement provisions. ${ }^{56}$ This reasoning is fallacious, however, since once the court determined that the drafters of the Act intended the civil liability to work as a penalty, the doctrine was inapplicable ${ }^{57}$ and there was no necessity for Congress to address this issue. The court further undermined this justification for inodifying the Act when it stated:

To the extent that only civil liability is pursued, the sanction against unscrupulous lomes sales practices is weakened. To the extent that only rescission is cliosen-where available-the penalty attendant upon nondisclosure will be less severe and, consequently, the incentive to disclose is diminished. ${ }^{68}$

The inference drawn from this statement is that enforcement of both sections of the Act is important to the policies which Congress wished to implement. Nevertheless, the Eby court suggested that there will be situations when, using its equitable discretion, the trial court can decline to enforce one of these provisions. ${ }^{59}$ This opimion, like the

54. 495 F.2d at 651 , citing Bostwick v. Cohen, 319 F. Supp. 875,877 (N.D. Ohio 1970).

55. 495 F.2d at 652 . It is ironic that the court justified modifications of the statute by emphasizing the harshness of the two forms of relief since it preinised the characterization of civil liability as a penalty on, inter alia, the necessity of severe enforcement provisions:

IIt would undermine effectiveness of the Truth in Lending Act to require borrowers to choose their remedies. The purpose of making creditors civilly liable is to force disclosure of credit terms. The purpose of according borrowers a right of rescission is broader; not only is it designed to compel disclosure, but it also serves to blunt unscrupulous sales tactics by giving homeowners a ineans to unburden themselves of security interests exacted by such tactics. Id.

56. Id. at 651 .

57. See text accompanying note 54 supra.

58. 495 F.2d at 652 .

59. The court's analysis suffers from the further defect that it failed to take account of section 1640 (c), which states:

A creditor may not be held liable in any action brought under this section for a violation of this chapter if the creditor shows by a preponderance of evidence that the violation was not intentional and resulted from a bona fide error notwithstanding the maintenance of procedures reasonably adapted to avoid any such error. 15 U.S.C. \$ 1640 (c) (1970).

This provision already seems to allow a creditor to escape an unjust application of this section. The use of an equitable discretion doctrine seems to invite the trial court to create other grounds upon which the creditor could avoid the application of the Act. If Congress had meant for the creditor to have other ways to escape the enforcement 
one in Ljepya, seems to be an inappropriate judicial modification of the Act.

The Ninth Circuit Court of Appeals employed the "equitable discretion" language used in Eby ${ }^{60}$ when, in Palmer $v$. Wilson, ${ }^{61}$ it judicially inodified the Act by ordering conditional rescission. In Palmer, a homeowners lending corporation extended credit to consumers ${ }^{62}$ without making the necessary disclosures. ${ }^{63}$ The consumers brought an action to recover the statutory penalty and to obtain enforceinent of their right of rescission. ${ }^{64}$ The district court awarded a civil penalty

of the Act, it could have enumerated them. Moreover, in some provisions of the Act, Congress deliberately took a harsh attitude toward creditors. See, e.g., id. $\S 1635$ (b) (creditor forfeits his consideration unless he reclaims it ten days after the consumer tenders it).

60. See text accompanying notes 45-46 supra.

61. 502 F.2d 860 (9th Cir. 1974).

62. Homeowners Loan Corporation extended a loan to the consumer in exchange for a note in the amount of $\$ 9300$ and a deed of trust securing the note. $359 \mathrm{~F}$. Supp. at 1100-01. This created the security interest in the consumer's residence necessary to trigger the rescission provision. If, however, the consumer had not owned any real property which was, or was expected to be, his principal residence at the time the credit transaction was entered into, he would never thereafter be extended the right of rescission under section 1635. If an after-acquired residence were to trigger the right of rescission, "the customer would obtain substantive rights that neither he nor the creditor could reasonably anticipate at the time . . ." Excerpts from FRB Letter of July 10, 1969, [1969-1974 Transfer Binder] CCH CONSUMER CREDIT Gume II 30,092, at 66,040. Similarly, one unust have a bona fide intent to live in a dwelling in order to call it his residence for purposes of section 1635. See Excerpts from FRB Letter of March 22, 1972 , No. 584, id. $\Uparrow 30,824$ at 66,360 . For example, if one enters into a credit transaction whereby the security interest is in a condominium in which he is entitled to reside for only thirty days of the year, significant questions arise as to business purpose and intent. Id. These problems inust be resolved on a case-by-case basis. See generally Burstein 85.

63. The lender failed to disclose in uniform terms, see 15 U.S.C. $\$ 1631$ (1970), the total payments due under the credit agreement, see id. $\$ 1639$ (a)(3), and the exact amount financed by the transaction, see id. $\$ 1639$ (a)(1). In addition, the consumers were not notified of their right to rescind as required by the Act. See id. $\S 1635(a)$; Regulation Z, 12 C.F.R. $\$ 226.9$ (a) (1974). The court concluded that there was "no question that defendants failed to make the required disclosures in proper form." 359 F. Supp. at 1101.

64. The homeowners mailed the defendant notice of rescission five and one half inonths after they had sigued a note and a deed of trust. $359 \mathrm{~F}$. Supp. at 1101. Heretofore, most commentators and courts have concluded that the right of rescission continued indefinitely until such time as the required disclosures were made. See, e.g., Palmer v. Wilson, 359 F. Supp. 1099, 1102 (N.D. Cal. 1973), vacated on other grounds, 502 F.2d 860 (9th Cir. 1974); Garwood, supra note 37, at 497 n.34; Comment, supra note 1, at 202; Note, Consumer Protection-Disclosure of Cognovit Provisions as Security Interests Under the Truth in Lending Act, 51 N.C.L. Rev. 874, 876 (1973). A recent amendment, however, has imposed a statute of limitations on the right of rescission:

(f) An obligor's right of rescission shall expire three years after the date of consummation of the transaction or upon sale of the property, whichever 
and attorney fees and ordered enforcement of the rescission. ${ }^{05}$ The court reasoned: "By sending their notice [of rescission] to defendants [creditors], plaintiffs [consumers] did all that was required of them. Defendant's claim that along with the notice plaintiffs ought to have tendered the money loaned them is expressly rejected [by the Act $] \ldots . . . " B b$

When the case was heard on appeal, the creditor argued that rescission had been improperly granted because the homeowners had not tendered the money loaned to them at the time they elected to rescind the agreement. ${ }^{07}$ Unlike the district court, the Ninth Circuit found merit in this argument:

[W] hen an obligor seeks to enforce his right of rescission, as well as to recover the statutory penalty and attorney fees, it is within the district court's equitable powier to grant both forms of relief, but to condition enforcement of the rescission order on the debtor's tender of the principal of the loan received from the creditor. The propriety of such a conditional decree of rescission, of course, will depend on the equities present in a particular case, as well as consideration of legislative policy ....88

The appellate court vacated the district court's judgment and "[remanded] the case for consideration of the propriety of conditioning the grant of rescission on repayment by the [consumers]." ${ }^{\prime 69}$

occurs earlier, notwithstanding the fact that the disclosures required under this section or any other material disclosures required under this chapter have not been dehivered to the obligor. Pub. L. No. 89-320, § 405 (Oct. 28, 1974), amending 15 U.S.C. \$ 1635 (1970).

65.359 F. Supp. at 1104 ; see 15 U.S.C. $\$ 1640$ (a) (1970).

66. $359 \mathrm{~F}$. Supp. at 1102 . This literal interpretaion of the statute has been recognized by other commentators. 'Melvin L. Burstein, General Counsel of the Federal Reserve Bank of Minneapolis, noted that "[b]ecause of the midnight deadline [on the third business day of the rescission period], the Task Force concluded that Congress intended for the most part, rescission shall take effect at the time notice is dispatched." Burstein 90. See also Kintner, Henneberger \& Neill, supra note 1, at 526; Comment, supra note 3 , at 132. It should be noted, however, that these interpretations were offered without the benefit of the Ninth Circuit's decision in Palmer v. Wilson, 502 F.2d 860 (9th Cir. 1974).

67. The creditor also argued that the plaintiff should have to elect between rescission and the civil penalty. Relying on Eby, the Palmer court rejected this contention. 502 F.2d at 861.

In addition, the creditor suggested that his failure to disclose was excused as an unintentional and bona fide error excused by 15 U.S.C. $\$ 1640$ (c) (1970). The court rejected this argument, stating: "The defendant's omissions and mislabeling of terms were not the result of clerical errors, which are the only violations this section was designed to excuse." 502 F.2d at 861, citing Ratner v. Chemical Bank N.Y. Trust Co., 329 F. Supp. 270, 281-82 (S.D.N.Y. 1971).

68. $502 \mathrm{~F} .2 \mathrm{~d}$ at 862 .

69. Id. The lower court was left in a true dilemma as to what test should be etrployed in determining whether or not to grant rescission. Presumably, when the Ninth 
This judicial modification of the Act is difficult to justify. The opinion of Judge Wright, concurring in part and dissenting im part, is better reasoned: "Although the remedy [of rescission] might be harsh, it is the one Congress adopted, and I would not substitute our judgment for its."'70 A literal interpretation of the Act would suggest that any security interest created by a credit agreement is void as soon as the consumer notifies the creditor of his intent to rescind. ${ }^{7 i}$ If, on the other lrand, rescission is not effective until tender by the obligor, the security interest of the creditor remains in force until such time as the consumer returns that which is the subject of the agreement. Judge Wright observed: "This is in direct conflict with $\S 1635(\mathrm{~b})$. Indeed, conditioning the voiding of a security interest on repayment is effectively no remedy at all because, after repayment, the security interest has fulfilled its purpose and has lost its vitality."72

The court cannot justify its modification of the Act on the basis that the Act's terms are so narrow that they fail to reach situations contemplated by Congress since conditional rescission limits the enforcement provisions even further than a literal interpretation. ${ }^{73}$ Similarly, as Judge Wright suggested, the language of the Act is not so ambiguous as to cause the prescribed statutory relief to be extended beyond the scope anticipated by the drafters. ${ }^{74}$ Instead, the Act vests an immed-

Circuit referred to the "equities" of the case, id., it intended to achieve a balancing of the amount of "harshness" to each party. The court cited the Eby decision for the proposition that a civil penalty and rescission of the contract "can sometimes result in an unduly harsh penalty" to the creditor. Id. On the other hand, it suggested that the obhgors may be ordered to restore the creditors' consideration in accordance with a plan that would take account of the obligor's "current financial situation." Id. at 863. At best, the district court may infer from the concurring opinion of Judge Thounpson that conditional rescission should be ordered only if the consumer will experience an econoinic "windfall" at the expense of the creditor. Id. at 864. This, of course, is still ambiguous, thus subjecting this test to the lower court's sense of justice and faimess.

Another test the Nuth Circuit suggested would be appropriate was whether the legislative policy of full disclosure is being effectively pursued. While the Eby decision might suggest that the enforcement provisions of the Act will be effective only if they are severe, see text accompanying note 58 supra, the lower court is placed in the untenable position of determining what degree of harshness is necessary to induce creditors to comply with the Act. Should this criteria be measured against the particular creditor involved or against creditors as a whole?

70. 502 F.2d at 864 (Wright, J., concurring in part and dissenting in part).

71. See note 27 supra and accompanying text.

72. 502 F.2d at 863 (Wright, J., concurring in part and dissenting in part).

73. See text accompanying note 52 supra.

74. It is well recognized that

general and coinprehensive legislation, prescribing minutely a course of conduct to be pursued and the parties and things affected, and specifically describing limitations and exceptions, is indicative of a legislative intent that the statute should totally supersede and replace cominon law dealing with the subject matter. 2 A C. SANDS, supra note 49, § 50.05, at 281 (4th ed. 1973). 
iate right of rescission in the consumer if his residence is used as collateral in certain credit transactions. ${ }^{75}$ Thus, the Palmer court's determination that the disclosure requirements of the Act had been violated should have been sufficient to affirm the consumer's substantive justification for voiding the contract. Its only remaining responsibility would then have been to order the restoration of the rescinding party's property.

Furthermore, it is particularly surprising that the Ninth Circuit would modify the terms to dilute the rights of the consumer since the rescission provision has been consistently characterized as remedial in nature, and it is the usual practice of the courts to give a liberal interpretation to such statutes. ${ }^{78}$ Thus, even if the court were to find some ainbiguity in the Act, normal rules of construction would suggest that the court should expand, rather than narrow, the Act's remedial effects.

See also S. Edgar, Craies on Statute Law 336-37 (6th ed. 1963). The briefest inspection of section 1635, together with the implementing provisions of Regulation $\mathrm{Z}$, would leave no doubt that the statute itself is quite precise in providing for the sequeuce of events that take place in rescission of a credit agreement and, in that respect, departs from common law. The sequence of rescission and tender provided by the common law is reversed by the Truth-in-Leuding Act and there is no reasonable explanation for reinstating the former.

75. One court has explained: "In substance, section 1635 vests a continuing power of rescission in the credit purchaser until three days following delivery of statutorily presclibed disclosures . . . ." Sosa v. Fite, 498 F.2d 114, 117 (5th Cir. 1974) (emphasis added). This right, however is now subject to a three year statute of limitations. See note 64 supra.

One of the recognized principles underlying this right of rescission and the three day waiting period is that the consumer will shop around to find the best credit terms available. See note 37 supra. This result has been questioned by commentators on two grouuds. First, it has been argued:

The effectiveness of [the Act] presupposes a cousumer who is able to shop around for the best buys in goods and services. Low income consumers may be forced by necessity to consider only monthly payments in making purchases and therefore may be unable to seek the best credit terms available. Garwood, supra note 37, at 502 .

Second, it has been suggested that the consumer normally does not read his credit agreement and by the time he does so, if ever, he has become so caught up in the transaction that he has already decided to make the purchase. See Note, supra note 1, at 107; Comment, supra note 31 , at 403 . If this proposition was true, the Palmer decision would presumably have little, if any, effect on creditors subject to the Act.

76. See, e.g., Mourning v. Family Publications Serv., Inc., 411 U.S. 356, 374-75 (1973); Eby v. Reb Realty, Inc., 495 F.2d 646, 650 (9th Cir. 1974); N.C. Freed Co. v. Board of Goveruors, 473 F.2d 1210, 1214 (2d Cir.), cert. denied, 414 U.S. 827 (1973); Gardner \& North Roofing \& Sidiug Co. v. Board of Goveruors, 464 F.2d 838, 841 (D.C. Cir. 1972); Starks v. Orleans Motors, Inc., 372 F. Supp. 928, 932 (E.D. La. 1974); Bostwick v. Cohen, 319 F. Supp. 875, 878 (N.D. Ohio 1970). See also C. SANDS, supra note $49, \S 60.01$, at 29 . The Eby court endorses the application of this principle to the Act: "The Truth in Lending Act is a remedial statute designed as much as possible to permit borrowers to make informed judgments about the use of credit. To 


\section{LITERAL INTERPRETATIONS OF THE ACT}

Other courts have declined to modify the Act judicially and have adopted a more literal interpretation. The Fifth Circuit took that approach in deciding Sosa v. Fite. ${ }^{77}$ In Sosa, an aluminum siding contractor, without making the statutorily required disclosures, induced one of his customers to sign a document creating a deed of trust on her home in the name of a savings bank. ${ }^{78}$ The homeowner made payments on the loan for alinost two years until she became dissatisfied with the "shoddy craftmanship"; 79 foreclosure and sale of her hoine to a third party followed soon thereafter. The homeowner gave the contractor and the savings bank notice of rescission and offered to return the aluminum siding. When they failed to respond, she successfully brought suit to enforce rescission of the contract. ${ }^{80}$ However, the district court also entered a judgment for the unpaid balance and impressed a judgment lien for that amount on her property. ${ }^{81}$ On appeal, the court concluded that tender by the obligor was not necessary for rescission of the contract. Instead, rescission was deened complete when the creditors were notified of Sosa's intent to rescind. ${ }^{82}$ Relying on the trial court's decision in Palmer, ${ }^{83}$ the court further maintained that the creditors "were unentitled to any tender at all" since they had failed to terminate their security interest and to return the obligor's property. ${ }^{84}$ Adhering to a literal interpretation, the Sosa court argued that the Act "contemplates an orderly progression of specific events," that

section $1635(\mathrm{~b})$ envisions responsive action on the creditor's part to a rescission notice, after which the debtor then becomes obligated to

effectuate this congressional purpose requires that the Act's terms be liberally construed." 495 F.2d at 650.

77. 498 F.2d 114 (5th Cir. 1974). A jurisdictional question in this case was decided in an earlier opinion. See 465 F.2d 1227 (5th Cir. 1972).

78. 498 F.2d at 116. The deed of trust was in favor of a savings and loan bank which had financed the liome improvement contract.

79. Id. at 116-17.

80. Id. at 117.

81. Id.

82. Id. at 121-22. The court further concluded:

[U]pon being notified of her rescission, Fite and Tropical were obligated to return all monies Sosa liad paid, with the statutorily embodied expectation that upon their further compliance with 1635 (b), Sosa would indisputably be obligated to tender either the property or its reasonable value. Id. at 120.

83. Id. at 118 (empliasis added). The Palmer trial court said: "By sending their notice to defendants, plaintiffs did all that was required of them." $359 \mathrm{~F}$. Supp. at 1102. This interpretation was, however, reversed by the Ninth Circuit. 502 F.2d at 862-63. See notes 61-69 supra and accompanying text.

84. 498 F.2d at 118 (emphasis added).

85. Id. 
tender either the property or a sum reflecting its reasonable value. This precise statutory scheme was abhorted [sic] in this case due to the creditor's failure to comply with statutory requirements, hence Sosa's responsibility to make the specific statutory tender was excused by the creditors' omissions. ${ }^{86}$

It is unclear whether the Palmer opinion, which was handed down after the Sosa decision, would have convinced the Fifth Circuit that tender might sometimes be required to effect rescission. The Sosa court did not consider the possibility of conditional rescission since the consumer tendered when she gave notice of her intent to rescind. Thus, even if the Fifth Circuit had conditioned rescission on tender, the result in Sosa would not have been changed. However, since the court stated without reservation that "under section 1635 a debtor's notice of rescission operates ipso facto to abrogate the contract,"87 it is doubtful that it would ever accept the doctrine of conditional rescission.

Having determined that the contract had been rescinded, the court further held that the creditors had forfeited the siding by not claiming it within ten days of tender by the obligor, thus reversing that part of the trial court's judgment which required the homeowner to pay the balance of the loan. ${ }^{88}$ The court concluded that since the creditor had never performed his obligations, the obligor's duty to tender ${ }^{89}$ never

86. Id. at 119 (emphasis added).

87. Id. at 121-22. The court explained: "[T]he section creates legal remedies which have binding legal effect absent court action." Id. at 121. This is reminiscent of the traditional rules of rescission at law which provided that a voidable contract could be rescinded by a debtor without a court decree. See note 19 supra and accompanying text. The Sosa opinion departed from the common law, however, in that the obligor need not tender the other party's property in order to effect rescission of the agreement. On the other hand, the Palmer decision would impose traditional rules requiring tender in at least some instances.

The Palmer approach is a legitimate means of construction for some statutes, given the well-accepted rules that statutes in derogation of the common law will be construed narrowly and will be interpreted with reference to the common law. The difficulty with this justification, however, is that these rules simply do not apply to this particular set of circumstances. One commentator has explained: "Although the rule of strict construction appears to load the scales in favor of common law rules against statutory ones, it is decisive in only a limited number of situations in which there is reasonable doubt as to the meaning of the statute." 3 C. SANDs, supra note $49, \S 61.03$, at 51 . It is suggested by this Note that no such reasonable doubt exists.

88. 498 F.2d at 119. Section 1635 (b) provides that "[i]f the creditor does not take possession of the property within ten days after teuder by the obligor, ownership of the property vests in the obligor without obligation on lis part to pay for it." 15 U.S.C. $\S 1635$ (b) (1970).

89. The customer must tender the property he received pursuant to the underlying agreement in specie unless to do so would be impracticable, in which case the reasonable 
arose. $^{90}$ The court reasoned that in the absence of a statutorily required tender, the forfeiture provision is not activated.91 However, the court was unwilling to permit a lack of cooperation by the creditor to defeat the consumer's right to forfeiture. It explained that to cut off the consumer's right for such a reason "would create a gross anomaly, for no tender in the exact scheme envisioned by the statute could ever be effected by a debtor in the most egregious of circumstances, naunely when a creditor steadfastly refuses to perform his express obligations upon receiving the notice of rescission." ${ }^{22}$ The court concluded, therefore, that if the creditor never discharged his obligations but the consumer tendered the consideration at the same time the notice of rescission was given, the forfeiture provision would be triggered. The court conceded, however, that in those cases where the creditor did perform his obligations, he would be entitled to a new statutory tender by the consumer before the ten-day forfeiture period would begin to run. ${ }^{93}$

The Fifth Circuit specifically distinguished the Ljepya decision, ${ }^{94}$ which ordered conditional rescission, on the basis that the borrowers

value thereof may be substituted. 15 U.S.C. $\$ 1635(b)$ (1970); see Regulation Z, 12 C.F.R. $\$ 226.9$ (d) (1974). It is contemplated that "the customer must take some affirmative action to tender the property to the creditor." Excerpts from FRB Letter of Oct. 31, 1969, [1969-1974 Transfer Binder] CCH Consumer CREDIT GuIDE \I 30,205, at 66,092 .

90. "Upon the performance of the creditor's obligations . . ., the obligor shall tender the [creditor's] property to the creditor." 15 U.S.C. $\$ 1635$ (b) (1970).

91. $498 \mathrm{~F} .2 \mathrm{~d}$ at 118-19. This is in accord with the court's "orderly progression of specific events" approach to the Act. The Fifth Circuit held that the obligor's "responsibility to make statutory tender" arises only upon performance by the creditor of his obligations and that normally the forfeiture provision is activiated only if the obligor's statutory tender is required.

92. Id. at 119. Given the court's literal imterpretation-that forfeiture may never arise unless the obligor is statutorily required to tender-the principles of judicial modification of a statute were appropriately applied. When the exact language of a statute is so narrow as to prevent its remedy from being applied to that which was intended by Congress, then it inay be modified by judicial construction. See note 52 supra and accompanying text. The irony here is that the Fifth Circuit's inisinterpretation of the statute is what gave rise to the necessity for modification.

93. Id. at 119 n.6. The court apparently contemplated two requirements for tender. One would be necessitated by the debtor's obligation to restore the creditor to the status quo ante. This is an essential element in the rescission of any contract. See notes 1516 supra and accompanying text. The other tender would be "statntorily" mandated in order to avoid a "disruptive coinmercial stand-off." Id. at 119.

The forfeiture provision seems to operate as a penalty on the creditor who fails to meet his obligations under the Act. It certainly cannot be characterized as a device designed to make the consumer whole, for it accomplishes more than that. If the forfeiture provision is deemed to be penal, questions arise as to the Eby court's decision. Was civil liability intended to be an additional penalty, or was it really remedial in nature?

94. See notes 36.40 supra and accompanying text. 
in that case had not attempted to return the proceeds of the loan whereas the homeowner in Sosa had offered to return the siding. ${ }^{95}$ This effort to distinguish the cases appears to be ineaningless. Such a consideration had no effect on the issue of rescission since the Sosa court clearly contemplated that the obhigor is always entitled to rescind if he notifies the creditor of his intent to do so. ${ }^{96}$ At best, the court was seeking to justify its position that tender at the moment of rescission will trigger the forfeiture provision even if the creditor never performs his obligations under the Act. ${ }^{97}$ Although both Ljepya and Palmer

95. $498 \mathrm{~F} .2 \mathrm{~d}$ at 119.

96. See id. at 121-22.

97. The court maintained that the creditors are not "unsuspecting victims of some complex regulatory entrapment" since they are informed by Federal Reserve Board Regulations that "no performance of a consumer credit contract be undertaken until the creditor has reasonably satisfied himself that the customer has not exercised his right of rescission." Id. at 120.

The right of rescission, of course, may be exercised at any time within three years of consummation of the credit agreement if the creditor has not properly disclosed the required information. Id. See note 31 supra and accompanying text. But even if there has been full disclosure, the consnmer may rescind the agreement for a period of three business days after consummation. 15 U.S.C. $\$ 1635$ (a) (1970).

The regulations state: "A transaction shall be considered consummated at the time a contractual relationship is created between a creditor and a customer irrespective of the time of performance of either party." Regulation Z, 12 C.F.R. $\$ 226.2$ (cc) (1974). Consnmmation apparently may be effected by (1) obtaining a loan commitunent from the creditor; (2) execution of the loan instrument which may be held in escrow until the cooling off period has run; (3) execution of a contract entitled "Consummation of Loan Secured by Real Property (Subject to Rescission by Borrowers)." See Clontz, Problems Encountered-And Some Solutions: Truth and Confusion in Lending, 87 BANRING L.J. 195, 208 (1970). The position of the Board is that "consummation occurs when a creditor agrees to extend credit and a customer agrees to utilize consumer credit." Excerpts from FRB Letter of Aug. 27, 1969, [1969-1974 Transfer Binder] CCH CoNSUMER CREDIT GUIDE $\Uparrow 30,146$, at 66,060 . In any case, it "follows that you must do something that would create a contractual relationship, under the laws of your State, in order to 'consummate the transaction' and be certain that the rescission period has started." 1 Truth-IN-Lending Manual $\|$ 503[11], at 5-38. See also Wachtel v. West, 476 F.2d 1062, 1065 (6th Cir. 1973); Excerpts from FRB Letter of Jnne 19, 1969, [1969-1974 Transfer Binder] CCH Consumer Credit GuIDE II 30,070, at 66,031-32; Comment, supra note 8, at 127 .

The absence of a definitive consummation date may work a hardship on the creditor who never knows whether or not he has really started the three day rescission period running. Similarly, if a consumer believes that the agreement has been consummated before any contractual obligation has arisen, the very purpose of the Act is defeated, since a security interest in the consumer's residence has not in reality been extended to the overreaching creditor. That is, until consummation, there is nothing to rescind. If the consumer thinks that the rescission period has run, even though there has in actuabity been no contract entered into, he is never provided the opportunity to withdraw a security interest that has been extended to the creditor. Arguably, some clarifications of consummation are needed in order to assure the effectiveness of the right of rescission and to protect the parties involved. See Burstein 88. 
turned on the issue of effective rescission, Sosa seemed to address their concern for harshness, but in the context of forfeiture. The Sosa court stated that the creditors' "lament of any inequity being visited upon them is utterly unpersuasive, for the power was completely theirs to prevent this parade of creditor horribles from ever occurring."98 This discussion of equity to the parties imports the concern of a court modifying the terms of a statute to achieve the results intended by Congress. ${ }^{99}$ The Sosa court, of course, thought it accomplished this by allowing tender at the moment of rescission to trigger the forfeiture provision. ${ }^{100}$ Ultimately, however, the court was unimpressed with the contention that the Act deals harshly with unenergetic creditors: "Congress' intended operation of the statute, as evidenced by the 1635(b) creditor-forfeiture provision . . . clearly calls for a debtor windfall if the creditor does not set about to rectify his earher nondisclosures in the manner envisaged by the statute."101

Another court has embraced the literal interpretation given to the rescission and forfeiture provisions of the Act by the Sosa court. In Hank's Auto Sales, Inc. v. Fisher, ${ }^{102}$ an Ohio appellate court applied all of the adverse provisions of the Act against a creditor who, like the Sos $a$ creditor, never responded to the consumer's notice of rescission. ${ }^{103}$

98. 498 F.2d at 120.

99. See notes 48-52 supra and accompanying text.

100. See note 91 supra. The Act requires the creditor to restore the consumer's property within ten days after receipt of notice of rescission. At that point, the obligor is required to tender and the creditor has ten days to take possession of his property. If the creditor was to perform his obligation under the Act, then tender at the time of rescission would clearly be ineffective to start the forfeiture provision running since to do so would allow the consumer to collapse the two separate two-day periods into one. In that situation, the obligor would be required to tender again if the creditor performed so that the creditor would be afforded his full opportunity to claim his goods before forfeiting them to the consumer. If the creditor does not perform within the ten-day period, he loses all rights to force the obligor to tender. But if the obligor does tender, and the creditor fails to claim his property within ten days, the forfeiture provision must be effective since the very purpose for its existence has been fulfilled-the creditor has had his full opportumity to claim his property and now must suffer the penalty for leaving the consumer in a position of continuous tender.

101. 498 F.2d at 119. Perhaps the Ninth Circuit with its pro-creditor bias would have been persuaded by the creditor's lament of mequity in Sosa; the Sosa court was unpersuaded by it because the creditors failed to carry out their statutory duties.

102. 38 Ohio App. 2d 1, 310 N.E.2d 259 (1973).

103. Even if one were to accept the Palmer doctrine that rescission may be conditioned on tender, the refusal of the creditors in Sosa and Hank's to ever meet their ob"ligations on notice of rescission might well suggest that the "equities" would be weighted in favor of the consumer. Furthernore, in Sosa the creditor was of a type toward whom the Act was directed. It was suggested, for example, in Gardner \& North Roofing \& Siding Corp. v. Board of Governors, 464 F.2d 838 (D.C. Cir. 1972), that "[t]he specific purpose of section $125(\mathrm{a}), 15$ U.S.C. $\S 1635$ (a), was to protect homeowners from the 
The consumer set up the Act as a defense to a cognovit note ${ }^{104}$ which showed an unpaid credit balance of over $\$ 400$. The court recognized that it was "constrained to apply the law as it is written"105 and went

unscrupulous business tactics of certain home improvement contractors." Id. at 841 . See also Hearings on S.J. Res. 130, S. 3065 and S. 3066 Before the Senate Commerce Comm., 90th Cong., 2d Sess. (1968). The Sosa case provided the ideal opportunity for the court to attack those practices which the Act was intended to curtail.

However, the idea that a more culpable creditor will be subjected to a more stringent interpretation of the Act is not valid. In Ljepya, for example, the creditor was accused by the court of being involved in a deliberate scheme to confuse the consumer, yet the court merely ordered conditional rescission. See notes 36-40 supra and accompanying text.

104. Regulation $Z, 12$ C.F.R. $\$ 226.2(\mathrm{z})$ (1974) provides:

"Security interest" and "security" mean any interest in property which secures payment or performance of an obligation. The terms include, but are not limited to, security interests under the Uniform Commercial Code, real property mortgages, deeds of trust, and other consensual or confessed liens whether or not recorded, mechanic's, materialmen's, artisan's, aud other similar liens, vendor's liens in both real and personal property, the interest of a seller in a contract for the sale of real property, any lien on property arising by operation of law, and any interest in a lease when used to secure payment or performance of an obligation.

Substantial criticism has been directed at the Board's inclusion of cognovit notes and statutory liens in the definition of "security interest." See 1 TRUTH-IN-LENDING MANUAL If 5.04[2], at 5-56 to 57 (1973). The argument is essentially that a security interest will not arise out of a cognovit note or statutory lien until such time as there has been a default by the obligor. The statute, however, extends the right of rescission only to credit transactions "in which a security interest is retained or acquired . . . ." 15 U.S.C. $\S 1635$ (a) (1970) (emphasis added). This clearly contemplates the present existence of a security interest rather than the mere possibility that one might arise in the future.

The courts, however, have thus far sustained the Board's authority to employ such a broad definition of security. In Gardner \& North Roofing \& Siding Corp. v. Board of Governors, 464 F.2d 838 (D.C. Cir. 1972), the court stated that since the Act was remedial in nature and must therefore be construed broadly,

[a] contract to renovate, remodel or repair a house imports that work will be done by mechanics and artisans and that materials will be furmished in connection with that work. Implicit in the contract, therefore, is a provision that a lien will attach to secure payment for the work aud materials . . . .

We think it a reasonable construction of the statute that Congress intended to require disclosure of all the consequences flowing from the signing of a home improvement contract, including not only the consequences spelled out in the contract but also those necessarily inherent therein. Id. at 841-42.

In N.C. Freed Co. v. Board of Governors, 473 F.2d 1210 (2d Cir.), cert. denied, 414 U.S. 827 (1973), the Second Circuit upheld the Board's definition by pointing out that in many states a statutory lien (such as a mechanic's lien) relates back to the date of the making of the contract. The court concluded that "[c]arving statutory liens out of the protection provided by Section 125 (a) would not only render impossible . . . uniformity among the states, it would defeat the goal of providing 'meaningful' disclosure to the consumer. We refuse to perform such a surgical procedure." Id. at 1216; $c f$. Douglas v. Beneficial Fin. Co., 469 F.2d 453 (9th Cir. 1972). See generally Burstein 84; Garwood, supra note 37, at 497-98. A recent amendment to the Act has specifically included within the purview of the Act any security interest "arising by operation of law." Pub. L. No. 89-320, § 404(1) (Oct. 28, 1974), amending 15 U.S.C. \$ 1635 (1970).

105. 38 Ohio App. $2 d$ at 3, 310 N.E.2d at 262. 
on to hold that the contract was rescinded and that the creditor had forfeited his property by failing to claim it within ten days of tender. In addition, the court awarded a civil penalty of $\$ 100$ and attorneys' fees of $\$ 750$.

The Hank's opinion did not discuss the relationship between tender and forfeiture; it only mentioned that the consumer gave notice of rescission. Since the creditor never responded, the act of giving notice seems to have been sufficient to trigger the forfeiture provision. ${ }^{100}$ This decision represents the toughest stance yet against a creditor, and cannot be reconciled with either Palmer or Sosa since apparently no tender was ever made. ${ }^{107}$ Such a stance clearly punishes those creditors who believe that if they disregard the Act, it will go away. Undoubtedly, its effect is shocking to many creditors, but such a shock is probably necessary if the substantial realignment of the debtor-creditor relationship mandated by the Act is to take place.

\section{CONDITIONAL RESCISSION AND CREDITOR FORFEITURE}

In the beginning of this Note, the example of a consumer who bought $\$ 2,000$ worth of storm windows was used to illustrate the basic elements of the rescission provision. ${ }^{108}$ This example will be useful now to point out the uncertainties that recent cases have created.

Suppose that the consunier did nothing more than notify the creditor of his imtent to rescind and that the creditor did not respond. Hank's would suggest that the full panoply of enforceinent provisionsrescission, forfeiture, civil penalty, and attorney fees-should be imposed. ${ }^{109}$ The Sosa decision would allow the contract to be rescinded on notice by the consumer but would not invoke forfeiture

106. It is interesting to note the different problems recognized by the Sosa and Hank's courts. In Sosa, the Fifth Circuit apparently felt that some sort of modification or loose interpretation of the Act was necessary to start the forfeiture provision running. On the other hand, the Hanks court expressed no such hesitancy and interpreted the Act as providing for forfeiture any time the creditor fails to respond to a consumer's tender.

107. The Palmer decision would apparently accept the argument that, in appropriate cases, a credit agreement may be rescinded without tender by the consumer. 502 F.2d at 862. Sosa, however, clearly stands for the proposition that the obligor must at some time offer to restore the creditor to his status quo ante before the forfeiture provision will be triggered. $498 \mathrm{~F} .2 \mathrm{~d}$ at 119 . Indeed, it is difficult to perceive how the ten-day period that creditors are allowed in which to claim their property fulfills its function if tender is never required. Very possibly, this was a misinterpretation by the Hank's court.

108. See text accompanying note 20 supra.

109. See 38 Ohio App. 2d at 5, 310 N.E.2d at 262-63. See notes 102-07 supra and. accompanying text. 
since that provision is not triggered until tender by the obligor. ${ }^{110}$ For purposes of the hypothetical, assume that in an effort to comply with Sosa the consumer tendered the storin windows to the creditor ten days after notice of rescission but still received no reply. A court following the Palmer-Ljepya rationale might reason that since the consuiner did not tender the storm windows when he notified the creditor of his intent to rescind, the contract was not rescinded and the creditor cannot be forced to forfeit his property. ${ }^{111}$

Such reasoning leaves the consumer in the untenable situation of exercising his right of rescission without knowing whether the court will subsequently cut off the forfeiture provision by holding the rescission to be ineffective due to the absence of tender at the time of the notice of rescission. Similarly, the creditor is left in a quandary as to whether or not he should ignore the notice of rescission and subsequent tender by the obligor in the hope that the court will hold that the notice of rescission was ineffective to void the creditor's security interest.

The Palmer and Sosa decisions would indicate that the only ineans by which a consumer can be sure of having available to him the forfeiture provision is always to tender at the inoment of rescission. The irony in this is that it returns the consuner to the disadvantageous position he suffered before the Act became effective. ${ }^{112}$ The contract may be rescinded, but the creditor has both his own property as well as the consuiner's consideration in his possession. The consumer then inust bear the burden of litigating to force the restoration of his property and at the same time assume the risk of creditor insolvency. This clearly was not the purpose of the Act.

\section{CONCLUSION}

The contradictory positions adopted in Palmer and Sosa have left the Act's rescission provision in an uncertain state. It is essential, therefore, that the Federal Reserve Board adopt regulations ${ }^{113}$ which

110. $498 \mathrm{~F} .2 \mathrm{~d}$ at 119 . See note 91 supra and accompanying text.

111. See Palmer v. Wilson, 502 F.2d 860, 862-63 (9th Cir. 1974); Ijepya v. M.L.S.C. Properties, 353 F. Supp. 866, 868 (N.D. Cal. 1973).

112. See text accompanying note 20 supra.

113. The Board is empowered to issue regulations by virtue of 15 U.S.C. $\$ 1604$ (1970):

The Board shall prescribe regulations to carry out the purposes of this subchapter. These regulations may contain such classifications, differentiations, or other provisions, and may provide for such adjustments and exceptions for any class of transactions, as in the judgment of the Board are necessary or proper to effectuate the purposes of this subchapter, to prevent circumvention or evasion thereof, or to facilitate compliance therewith. 
state that tender may never be a condition of rescission but is always a prerequisite to forfeiture. This would essentially result in rejecting the Palmer and Ljepya decisions on rescission and the Hank's position on forfeiture, while adopting the Sosa interpretation on both issues. Although the courts are not bound by the Board's regulations, the regulations certainly are accorded significant weight. ${ }^{114}$ At a minimum, such regulations might force a Supreme Court decision on the issues which now remain unsettled. Until a definitive answer by the appropriate authority removes the consumers' uncertainties as to his obhigations and remedies under the Act, overreaching creditors will continue to evade the requirements of full disclosure.

Griffith L. Garwood, an advisor to the Legal Division of the Board of Governors of the Federal Reserve System, has pointed out in a receut article that although the Board is authorized to issue regulations which are enforced by a number of different agencies, see 15 U.S.C. $\$ 1607$ (1970), the interpretations of the regulations offered by the Board are not always followed by the courts. See Garwood, supra note 37, at 49394. Although the courts may lend great weight to the Board's own interpretations, such opinions do not have the force of law. See Ratner v. Chemical Bank N.Y. Trust Co., 329 F. Supp. 270, $278-79$ (S.D.N.Y. 1971). Indeed, for the regulations themselves to be given effect by the judiciary, they must be "reasonably related to the purposes of the enabling legislation." Mouruing v. Family Publications Serv., 411 U.S. 356, 369 (1973), citing Thorpe v. Housing Authority, 393 U.S. 268, 280-81 (1969). See generally Garwood, Truth-in-Lending After Two Years, 89 BANkrNg L.J. 3, 8 (1972); Comment, supra note 31, at 391 n.18; Note, Consumer Protection-Truth-in-Lending Disclosures Not Timely at Closing, 51 N.C.L. REv. 592 (1973).

114. See Ratner v. Chemical Bank N.Y. Trust Co., 329 F. Supp. 270, 278-79 (S.D.N.Y. 1971). 